\title{
Effects of Lime Application and Understory Removal on Soil Microbial Communities in Subtropical Eucalyptus L'Hér. Plantations
}

\author{
Songze Wan ${ }^{1}$, Zhanfeng Liu ${ }^{2}$, Yuanqi Chen ${ }^{3}$, Jie Zhao ${ }^{4}$, Qin Ying ${ }^{1}$ and Juan Liu ${ }^{1, *}$ \\ 1 Collaborative Innovation Center of Jiangxi Typical Trees Cultivation and Utilization, College of forestry, \\ Jiangxi Agriculture University, Nanchang 330045, China; swan0722@jxau.edu.cn (S.W.); \\ yingqinww@163.com (Q.Y.) \\ 2 Key Laboratory of vegetation Restoration and Management of Degradation Ecosystems, South China \\ Botanical Garden, Chinese Academy of Sciences, Guangzhou 510650, China; liuzf@scbg.ac.cn \\ 3 Hunan Province Key Laboratory of Coal Resources Clean-utilization and Mine Environment Protection, \\ Hunan University of Science and Technology, Xiangtan 411201, China; chenyq2016@163.com \\ 4 Key Laboratory of Agro-ecological Processes in Subtropical Region, Institute of Subtropical Agriculture, \\ Chinese Academy of Sciences, Changsha 410125, China; jzhao@isa.ac.cn \\ * Correspondence: liujuan@jxau.edu.cn
}

Received: 7 March 2019; Accepted: 13 April 2019; Published: 16 April 2019

check for updates

\begin{abstract}
Soil microorganisms play key roles in ecosystems and respond quickly to environmental changes. Liming and/or understory removal are important forest management practices and have been widely applied to planted forests in humid subtropical and tropical regions of the world. However, few studies have explored the impacts of lime application, understory removal, and their interactive effects on soil microbial communities. We conducted a lime application experiment combined with understory removal in a subtropical Eucalyptus L'Hér. plantation. Responses of soil microbial communities (indicated by phospholipid fatty acids, PLFAs), soil physico-chemical properties, and litter decomposition rate to lime and/or understory removal were measured. Lime application significantly decreased both fungal and bacterial PLFAs, causing declines in total PLFAs. Understory removal reduced the fungal PLFAs but had no effect on the bacterial PLFAs, leading to decreases in the total PLFAs and in the ratio of fungal to bacterial PLFAs. No interaction between lime application and understory removal on soil microbial community compositions was observed. Changes in soil microbial communities caused by lime application were mainly attributed to increases in soil $\mathrm{pH}$ and $\mathrm{NO}_{3}{ }^{-}-\mathrm{N}$ contents, while changes caused by understory removal were mainly due to the indirect effects on soil microclimate and the decreased soil dissolved carbon contents. Furthermore, both lime application and understory removal significantly reduced the litter decomposition rates, which indicates the lime application and understory removal may impact the microbe-mediated soil ecological process. Our results suggest that lime application may not be suitable for the management of subtropical Eucalyptus plantations. Likewise, understory vegetation helps to maintain soil microbial communities and litter decomposition rate; it should not be removed from Eucalyptus plantations.
\end{abstract}

Keywords: lime application; understory removal; microbial community; forest management; Eucalyptus

\section{Introduction}

Soil microorganisms play essential roles in regulating ecosystem processes and maintaining ecosystem functions and services, such as litter decomposition [1], nutrient cycling [2], primary production, and climate regulation [3]. Both biotic and environmental factors drive the activity, 
structure, and diversity of soil microbial communities, which are controlled by many factors including edaphic conditions [4]. Soil microbes generally respond quickly to environmental changes. Although numerous previous studies have explored the soil microbial responses to environmental changes in various forest types, more quantitative research estimating the effects of forest management practices on soil microbial community compositions is needed [5,6]. Information from such studies is valuable in both theoretical and practical aspects, which will improve our understanding of the mechanisms underlying soil carbon and nutrient cycling in forest ecosystems and may support sustainable forest management.

Acrisol is a common type of soil, distributed mainly in humid tropical/subtropical and even warm temperate regions, such as Southern Asia, South China, and Southeast US [7]. Lime application is one of the most widely applied management practices for amending Acrisol [8]. In addition to lowering soil acidity, lime application could improve soil structure, and thus typically promote agriculture and forest productivities $[4,9]$. Lime application also affects soil biological and biochemical properties, including microbial activities and carbon and nitrogen mineralization [7]. Previous studies investigating the effects of liming on soil microbial community composition reported mixed results. For example, both Pennanen et al. (1998) and Pawlett et al. (2009) found that lime application significantly reduced bacterial phospholipid fatty acids (PLFAs) and did not affect fungal PLFAs [10,11]. While Bruneau et al. (2010) reported that the density of bacteria was increased by liming [12]. Kamal et al. (2010) found that lime application led to increases in the relative abundance of prokaryotes, bacilli, and actinomycetes but decreases in micromycetes [13]. On the contrary, Wang et al. (2007) reported an inhibitory effect of lime on actinomycetes that could facilitate soil carbon mineralization [14]. Although the acid tolerance of individual microbial species varies widely, it is well recognized that low $\mathrm{pH}$ inhibits the growth of soil bacteria but favors fungi that are more resistant to acidity. Therefore, the soil microbial community generally shifts from fungi to bacteria as the $\mathrm{pH}$ increases after lime application [15]. However, most of these studies focused on the soil microbial communities in agricultural soil $[8,16]$. We still have a poor understanding of how fungal and bacterial communities respond to lime application in forests, especially for Eucalyptus plantations in South China where soils are strongly acidic.

Eucalyptus urophylla S.T.Blake is a fast-growing species and is widely planted in South China. Due to the high demand for wood and fiber, the planting area of E. urophylla is expanding [17]. Within an E. urophylla plantation, the understory vegetation is typically dominated by a native fern Dicranopteris dichotoma (Thunb.) Bernh., which usually forms a mat-like dense layer beneath the open-canopy areas [6,17]. Several studies have revealed that understory vegetation plays important roles in maintaining both the aboveground and belowground biodiversity, the microclimate, and the nutrient cycling $[1,6,18]$. Furthermore, understory fern biomass can occupy up to $20 \%$ of the total biomass in Eucalyptus plantations [19], indicating that understory plants could make a substantial contribution to the regulation of soil processes. Although the number of such studies is growing recently, the importance of understory vegetation in driving ecosystem structure and functions remains unfocused in most ecological studies [20,21]. In practice, understory vegetation is usually removed to reduce competition for nutrients against plantation trees, which could facilitate the growth of tree seedlings [22] and cause significant changes in soil microclimates [20] or nutrient availabilities [23]. To date, however, only a few studies quantitatively determined the effects of understory removal on soil microbial community composition, especially in combination with other forest management practices, and the effects tend to be conflicting. Some studies reported significant alterations in the composition of soil microbial communities [6,24], while others did not [25]. Therefore, the effects of understory removal on soil microbial communities are highly context dependent and need to be further studied.

In the present study, a lime application experiment combined with understory removal was conducted in a subtropical E. urophylla plantation to examine the main and interactive effects of lime application and understory removal on soil microbial community composition. We hypothesized that: (1) Lime application would increase soil $\mathrm{pH}$, leading to negative effects on fungal biomass but positive effects on bacterial biomass, hence, changing the microbial composition, because most fungi 
are moderately acidophilic but bacterial species could grow within wider $\mathrm{pH}$ ranges; and (2) understory removal would result in negative effects on soil microbial biomass and composition, due to reductions of belowground resource inputs and changes in soil microclimates.

\section{Materials and Methods}

\subsection{Site Description}

This study was conducted in three six-year old E. urophylla monoculture plantations at Heshan National Field Research Station of Forest Ecosystem (112 $50^{\prime}$ E, $\left.22^{\circ} 34^{\prime} \mathrm{N}\right)$, Chinese Academy of Science (CAS), Guangdong Province, China. Each of the three plantations occupied about 1 ha. The distance between any two plantations exceeded $1 \mathrm{~km}$. The climate in this region is typically subtropical monsoon, with a humid hot season from April to September and a dry cold season from October to March. The mean annual temperature and rainfall are $21.7^{\circ} \mathrm{C}$ and $1700 \mathrm{~mm}$, respectively. The soil is classified as an Ultisol developed from sandstone [26]. Eucalyptus plantations were reestablished in 2005 after all previous trees (Pinus elliottii Engelm.) had been cut, with saplings planted at a spacing of $3 \mathrm{~m} \times 2 \mathrm{~m}$ (1650 trees per ha). The understory vegetation within the plantation was dominated (almost $100 \%$ ) by D. dichotoma, accompanied by some rarely occurring species such as Rhodomyrtus tomentosa (Aiton) Hassk. and Miscanthus sinensis Andersson.

\subsection{Experiment Design}

A split-plot design was used and four treatments were replicated three times, with the lime application as the main-plot factor and understory removal as the sub-plot factor. In December 2011, two paired main-plots were established in each plantation, and within each main plot, a sub-plot was distinguished. The main-plot size was $10 \mathrm{~m} \times 10 \mathrm{~m}$, while the sub-plot size was $5 \mathrm{~m} \times 5 \mathrm{~m}$. Lime application and understory removal were arranged for the main plot and the sub-plot, respectively. Therefore, the four treatments were: Control without lime application and with intact understory (CK), understory removal (UR), lime application (LA), and lime application combined with understory removal (LUR). Around each plot, polyvinyl chloride (PVC) boards were embedded at a depth of $80 \mathrm{~cm}$ to exclude disturbance from roots outside the plots and to eliminate the movement of water and nutrients. For plots receiving lime application, lime was added to the soil surface on 15 December 2011 and 15 August 2012 in the form of pulverized lime (60 kg per $100 \mathrm{~m}^{2}$ as CaO in total per year). Understory vegetation (including the above- and belowground components) was physically removed from plots for the understory removal treatments (i.e., UR and LUR) prior to the start of the experiment. Any understory plant germinated during the experimental period was removed on a monthly basis.

\subsection{Soil Sampling and Analysis}

Soils were sampled on $0,10,60,147,275$, and 377 days after the treatments were applied, with the day 0 sample as the baseline. The surface litter was carefully removed before sampling. In each plot, five soil cores $(2.5 \mathrm{~cm}$ in diameter) at $0-10 \mathrm{~cm}$ depth from random sampling points were combined as one composite sample. After carefully removing the surface organic materials and visible roots, each composite sample was passed through a $2 \mathrm{~mm}$ sieve and divided into two subsamples; one subsample was stored at $4{ }^{\circ} \mathrm{C}$ for soil physical-chemical analysis, and the other was stored at $-20^{\circ} \mathrm{C}$ for PLFA analysis.

Soil $\mathrm{pH}$ was measured every month during the experimental period. Three soil cores at 0-10 cm depth were sampled in each plot and combined as a composite sample. Soil $\mathrm{pH}$ was determined in a 1:2.5 soil-water slurry using a combination glass electrode. Soil temperature was measured with the

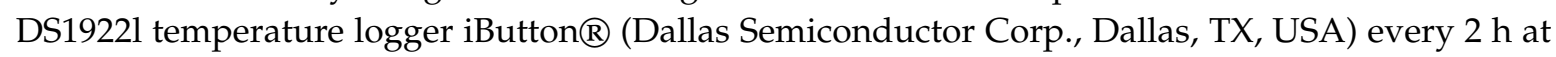
$5 \mathrm{~cm}$ soil depth in situ from December 2011 to December 2012. Soil moisture contents (SMC\% g of water per $100 \mathrm{~g}$ of dry soil) was determined gravimetrically after the soil was dried for $48 \mathrm{~h}$ at $105^{\circ} \mathrm{C}$. 
The soil microbial community was characterized by the phospholipid fatty acid (PLFA) analysis [27,28]. Briefly, field-moist, sieved soil samples equivalent to $8 \mathrm{~g}$ dry mass were extracted in a chloroform-methanol-phosphate buffer (1:2:0.8 v/v/v), and the extracted lipids were fractionated into neutral lipids, glycolipids, and polar lipids on silica acid columns by successive elution with chloroform, acetone, and methanol. The methanol fraction (containing phospholipids) was subjected to mild alkaline methanolysis to transform the fatty acids into free methyl esters and was analyzed on a gas chromatograph (Hewlett-Packard 6890, Agilent, Santa Clara, CA, USA). Peaks were identified using bacterial fatty acid standards and MIDI peak identification software (MIDI, Inc., Newark, DE, USA). Concentrations of each PLFA were standardized relative to 19:0 internal reference concentrations. Fungal biomass was considered to be indicated by 18:2 $\omega 6,9$ [28]; bacterial biomass was considered to be indicated by the following 10 PLFAs: i15:0, a15:0, 15:0, i16:0, 16:1w7, i17:0, a17:0, 17:0, cy17:0, and cy19:0; total PLFAs and the ratio of fungal to bacterial PLFAs were also calculated. All PLFAs were calculated as ng g ${ }^{-1}$ dry soil.

\subsection{Litter Decomposition Experiment}

Litter bags $(26 \mathrm{~cm} \times 15 \mathrm{~cm}$ with a mesh size of $1 \mathrm{~mm} \times 1 \mathrm{~mm})$ were used to measure Eucalyptus litter decomposition rates. Fresh Eucalyptus litter was collected from litter traps ( $1 \mathrm{~m} \times 1 \mathrm{~m}$ nylon net) in the experimental plantation. Each litter bag contained $10 \mathrm{~g}$ oven-dried litter, and six litter bags were placed on the soil surface in each subplot of the four treatments in December 2011. Afterward, one litter bag in each subplot was harvested bimonthly until all the six bags were harvested. The retrieved litter decomposition residuals were collected and oven-dried at $65^{\circ} \mathrm{C}$ to a constant mass, and then weighed for the mass. The litter decomposition rate was calculated as the bimonthly mass loss rate: Litter decomposition rate $(\%)=$ (mass loss bimonthly/initial weight of litter) $\times 100 \%$, where the initial weight of litter in each litter bag was $10 \mathrm{~g}$.

\subsection{Statistical Analysis}

Repeated-measure ANOVAs by the general linear model were employed to examine the effects of time and treatments throughout the experimental period. Soil physico-chemical properties and microbial biomass measured during the experiment were analyzed using linear mixed-effect models, with lime application and understory removal as categorical fixed effects, and replicated $(n=3)$ as a random effect. Redundancy analysis (RDA) was performed to determine the relationships between microbial communities (PLFA profile) and soil physico-chemical properties. The most discriminating soil property variables were selected by the "forward selection" procedure. Data were transformed (natural log, square root, or rank) when necessary to meet assumptions of normality and homogeneity of variance. Statistical significance was determined at $P \leq 0.05$. All univariate analyses were performed in SPSS 18.0 (SPSS Inc., Chicago, IL, USA). RDA was performed with the CANOCO 4.5 software (Ithaca, NY, USA). The forward selection was implemented based on the Monte Carlo permutation $(n=499)$.

\section{Results}

\subsection{Soil Physico-Chemical Properties}

Contents of soil organic carbon (SOC), total nitrogen (TN), dissolved organic carbon (DOC), as well as soil $\mathrm{pH}$, did not differ among plots before the treatments were applied (Table 1), indicating no spatial heterogeneity between the experimental plots. Soil $\mathrm{NH}_{4}{ }^{+}-\mathrm{N}$ contents varied with time but did not differ among the four treatments during the experimental period (Table 2). Soil $\mathrm{pH}$, however, was significantly higher in the LA treatment (4.19-4.56 units) than in the control (3.78-3.83 units) or the UR treatment (3.57-3.87 units) across the sampling events (Figure 1). Soil $\mathrm{NO}_{3}{ }^{-}-\mathrm{N}$ contents were increased by LA, but decreased by UR. Soil moisture contents (SMC) were significantly lower in both LA and UR treatments than in the control. For DOC, there was a slight decline in the UR treatment, but the trend 
was minimal $(P=0.06)$. In addition, no interaction between LA and UR on any soil physico-chemical property measured in this study was observed (Table 2).

Table 1. Soil characteristics before treatments were applied.

\begin{tabular}{ccccc}
\hline Treatments & SOC $\left(\mathbf{g ~ k g}^{-\mathbf{1}}\right)$ & TN $\left(\mathbf{g ~ k g}^{-\mathbf{1}}\right)$ & DOC $\left(\mu \mathbf{g ~ C ~}^{\mathbf{- 1}}\right)$ & pH \\
\hline Control & $14.43(0.66)$ & $1.86(0.32)$ & $288.64(74.26)$ & $3.97(0.04)$ \\
UR & $15.78(1.82)$ & $1.72(0.53)$ & $268.11(88.39)$ & $4.05(0.04)$ \\
LA & $17.06(1.95)$ & $1.68(0.37)$ & $249.22(62.16)$ & $4.14(0.02)$ \\
LUR & $15.64(1.21)$ & $1.71(0.47)$ & $246.54(46.55)$ & $4.16(0.01)$ \\
ANOVA & ns & ns & ns & ns
\end{tabular}

SOC, soil organic carbon; TN, total nitrogen; DOC, dissolved organic carbon; Control, no lime application and no understory removal; UR, understory removal; LA, lime application; LUR, lime application with understory removal. Values are means (with SE in parentheses; $n=3$ ). Statistical significance was determined at $P<0.05$. ns, no significant difference between treatments using ANOVA.

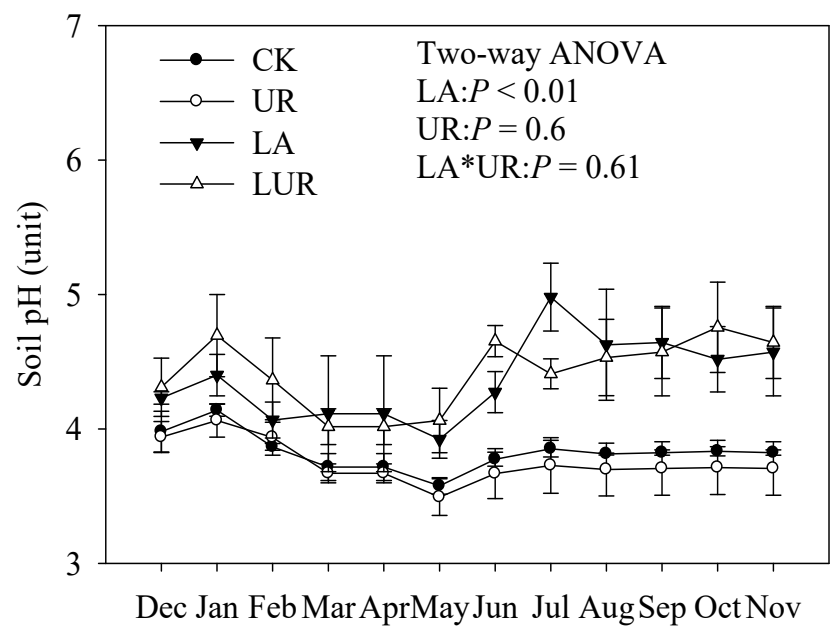

Figure 1. Soil $\mathrm{pH}$ under different treatments during the experimental period. $\mathrm{CK}$, control without lime application and with intact understory; UR, understory removal; LA, lime application; LUR, lime application with understory removal. Values are means $\pm \mathrm{SE}, n=3$.

Table 2. Effects of time, lime application, understory removal, and the interaction of lime application and understory removal on soil moisture content, soil temperature at $0-5 \mathrm{~cm}$ depth, dissolved organic carbon, and inorganic nitrogen content, $n=3$.

\begin{tabular}{ccccccccc}
\hline \multirow{2}{*}{ Factors } & \multicolumn{2}{c}{ Time } & \multicolumn{2}{c}{ LA } & \multicolumn{2}{c}{ UR } & \multicolumn{3}{c}{ LA $\times$ UR } \\
\cline { 2 - 9 } & $\boldsymbol{F}$ & $\boldsymbol{P}$ & $\boldsymbol{F}$ & $\boldsymbol{P}$ & $\boldsymbol{F}$ & $\boldsymbol{P}$ & $\boldsymbol{F}$ & $\boldsymbol{P}$ \\
\hline SMC & 15.14 & $<0.01$ & 20.45 & $<0.01$ & 9.4 & $<0.01$ & 2.56 & 0.112 \\
$\mathrm{ST}$ & 12.15 & $<0.01$ & 3.57 & 0.09 & 36.4 & $<0.01$ & 1.05 & 0.34 \\
$\mathrm{DOC}$ & 1.45 & 0.2 & 0.95 & 0.33 & 0.18 & 0.06 & 0.23 & 0.63 \\
$\mathrm{NH}_{4}{ }^{+}-\mathrm{N}$ & 7.15 & $<0.01$ & 0.27 & 0.6 & 2.31 & 0.14 & 2.2 & 0.99 \\
$\mathrm{NO}_{3}{ }^{-}-\mathrm{N}$ & 26.01 & $<0.01$ & 27.13 & $<0.01$ & 13.31 & $<0.01$ & 0.99 & 0.32 \\
\hline
\end{tabular}

Time, sampling time; LA, lime application; UR, understory removal; LA $\times$ UR, interactions between lime application and understory removal; SMC, soil moisture content; ST, soil temperature; DOC, dissolved organic carbon. Results are from a three-way factorial ANOVA, with factors of time (levels: Dec 2011, Feb 2012, May 2012, Sep 2012, and Dec 2012), lime application (levels: limed, not limed), and understory removal (levels: understory removed, understory not removed).

\subsection{Soil Microbial Community}

Soil microbial biomass (as indicated by the total PLFAs, i.e., the sum of fungal and bacterial PLFAs) ranged from 453 to $2701 \mathrm{ng} \mathrm{g}^{-1}$ under different treatment during the experimental period. Sampling time had a significant effect on total PLFAs, bacterial PLFAs, fungal PLFAs, and the F:B ratio (ratio of 
fungal to bacterial PLFAs) (Figure 2, Table 3). Across sampling time, the LA treatment significantly decreased both fungal and bacterial PLFAs and hence the total PLFAs, but had no significant effect on the F:B ratio (Figure 2, Table 3). The UR treatment, however, significantly decreased the fungal and total PLFAs without affecting bacterial PLFAs, and thus reduced the F:B ratio (Figure 2, Table 3). There were no significant interaction effects of LA and UR on the composition of soil microbial communities during the entire experimental period. In addition, no interaction effect between sampling time and LA was observed, while the interaction between sampling time and UR on the total PLFAs was remarkable (Table 3).

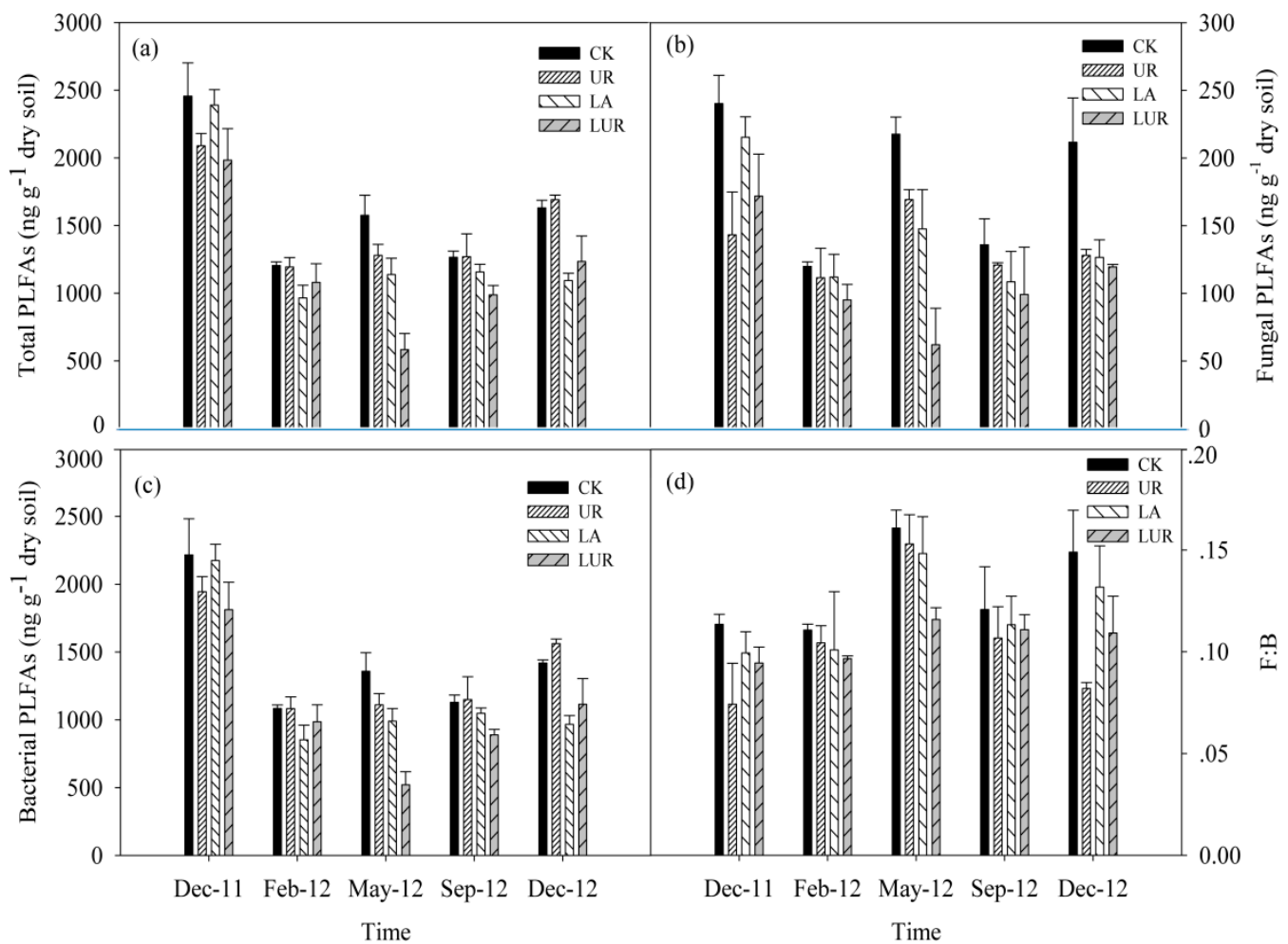

Figure 2. Soil microbial phospholipid fatty acids (PLFAs) under different treatments. (a) Soil Total PLFAs; (b) Soil Fungal PLFAs; (c) Soil Bacterial PLFAs; (d) the Ratio of Fungal PLFAs to Bacterial PLFAs. UR, understory removal; LA, lime application; LUR, lime application with understory removal. F:B indicates the ratio of fungal to bacterial PLFAs. Values are means $\pm \mathrm{SE}, n=3$.

Table 3. Effects of time, lime application, understory removal, and interactions between time, lime application and understory removal on soil microbial PLFAs, $n=3$.

\begin{tabular}{cccccccc}
\hline \multirow{2}{*}{ Variable } & Time & LA & UR & LA $\times$ UR & Time $\times$ LA & Time $\times$ UR & Time $\times$ LA $\times$ UR \\
\cline { 2 - 8 } & $\boldsymbol{P}$ & $\boldsymbol{P}$ & $\boldsymbol{P}$ & $\boldsymbol{P}$ & $\boldsymbol{P}$ & $\boldsymbol{P}$ & $\boldsymbol{P}$ \\
\hline Total PLFAs & $<0.01$ & $<0.01$ & 0.02 & 0.65 & 0.64 & 0.02 & 0.81 \\
Bacteria PLFAs & $<0.01$ & $<0.01$ & 0.14 & 0.79 & 0.24 & 0.07 & 0.94 \\
Fungal PLFAs & $<0.01$ & $<0.01$ & $<0.01$ & 0.46 & 0.06 & 0.08 & 0.21 \\
F:B & $<0.01$ & 0.76 & 0.02 & 0.74 & 0.65 & 0.26 & 0.38 \\
\hline
\end{tabular}

Time, sampling time; LA, lime application; UR, understory removal; LA $\times$ UR, interactions between lime application and understory removal; F:B indicates the ratio of fungal to bacterial PLFAs. Results are from a three-way factorial ANOVA, with factors of time (levels: Dec 2011, Feb 2012, May 2012, Sep 2012, and Dec 2012), lime application (levels: limed, not limed), and understory removal (levels: understory removed, understory not removed).

\subsection{Relationships between Soil Physico-Chemical Properties and Microbial Community}

Redundancy analysis showed that soil microclimate $(P<0.01)$, soil DOC $(P<0.01)$, soil $\mathrm{pH}$ $(P=0.02)$, and soil $\mathrm{NO}_{3}{ }^{-}-\mathrm{N}$ content $(P=0.02)$ were significantly correlated with whole soil microbial 
communities (Figure 3). Specifically, soil pH and SMC were correlated negatively to 18:2 $\omega 6,9, \mathrm{i} 16: 0$, 15:0, and a17:0 (Figure 3). Soil temperature was correlated positively to i17:0 and negatively to a15:0, i15:0, and 16:1 $\omega 7$ (Figure 3). Soil $\mathrm{NO}_{3}{ }^{-}-\mathrm{N}$ content and soil DOC, however, were correlated negatively to i17:0, but correlated positively to a15:0, i15:0, and 16:1 17 (Figure 3). All the environmental data explained $92.4 \%$ of the total variance, with the first axis (Axis 1 ) explaining $66.3 \%$ of the variance and the second axis (Axis 2) explaining another 26.1\% (Figure 3).

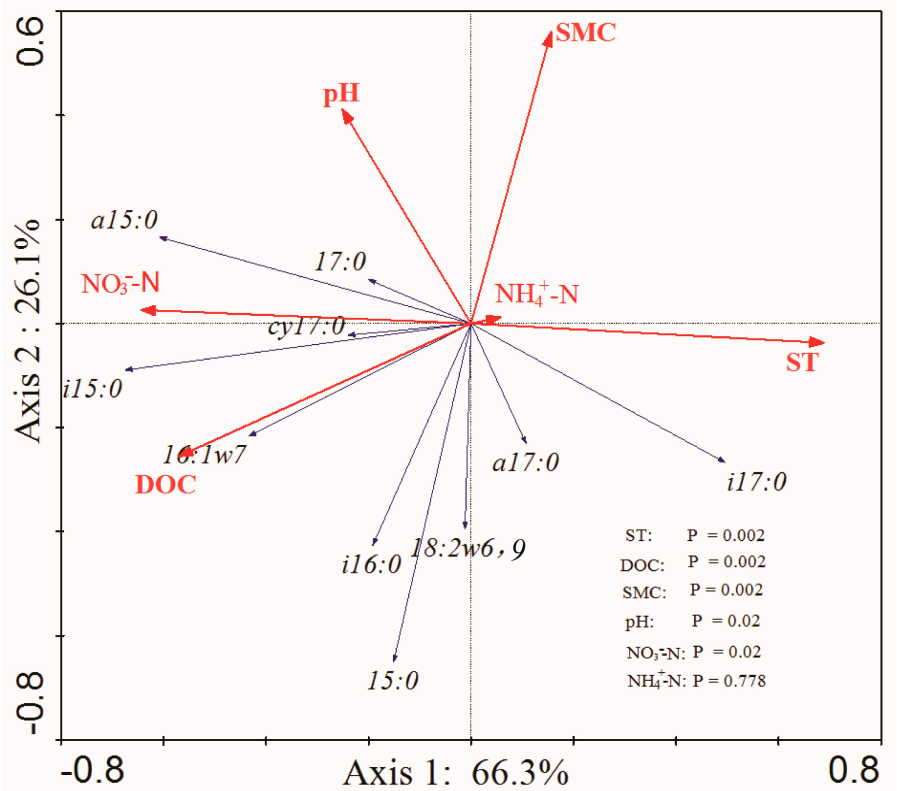

Figure 3. Redundancy analysis of soil microbial PLFA biomarkers. Ordination diagrams presenting species scores and environmental factor scores (vectors). ST, soil temperature at $0-5 \mathrm{~cm}$ depth; DOC, dissolved organic carbon; SMC, soil moisture content.

\subsection{Litter Decomposition}

One year after the treatments were applied, both LA and UR treatments significantly reduced litter mass loss (both $P<0.01$ ). There was no significant interaction of LA and UR on the litter mass loss during the experimental period (Figure 4).

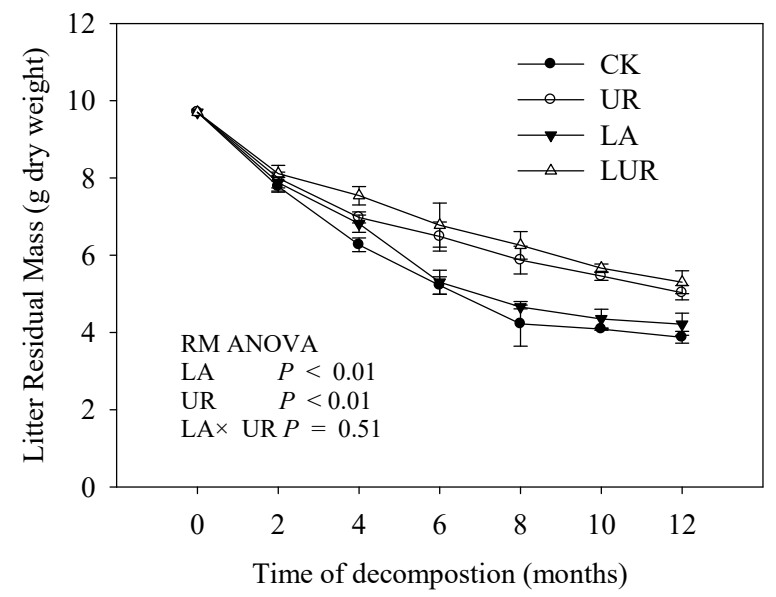

Figure 4. Mass of Eucalyptus litter remaining per litter bag under different treatments. Vertical bars represent SEs. LA, lime application; UR, understory removal. The inserted $P$ values were from repeated-measure ANOVA. 


\section{Discussion}

\subsection{The Impacts of Lime Application on Soil Microbial Community}

Liming is commonly used to improve environmental conditions for the development of acid-intolerant microbes, resulting in increased microbial biomass and activities [4,29]. In this study, however, we observed a reduction of soil fungal and bacterial PLFAs after lime application. Consistent with our results, some other studies have also found that lime application inhibited the soil microbial biomass in both field- and lab-based conditions. For instance, Pawlett et al. (2009) reported that liming decreased soil microbial PLFAs and bacterial PLFAs [11]. Lin et al. (2018) also found that some soil bacterial groups were consistently decreased by a 27-year lime application in South China, and lime application may potentially affect the $\mathrm{N}$-fixation ability by altering the soil community structure of soil diazotrophs [30]. Lime application did not affect soil the F:B ratio in this study, due to the decreases in both fungal and bacterial PLFAs (Figure 2, Table 3). Likewise, Xue et al. (2010) observed that liming had minimal effects on the F:B ratio, though soil microbial community structure had been significantly affected [31].

The most likely reason for lime application inducing alterations in soil microbial biomass may be associated directly with the increased soil $\mathrm{pH}$, as shown by the fungal biomarker 18:2 $\omega 6,9$, and the bacterial biomarkers $a 17: 0, i 16: 0$, and 15:0 were correlating negatively with soil pH (Figure 3 ). It is well recognized that most fungi are moderately acidophilic [7], and therefore, the fungal activities would be inhibited and the microbial communities would typically shift from fungal to bacterial as soil $\mathrm{pH}$ increased after lime application. Furthermore, the signature of $a 17: 0, i 16: 0$, and 15:0 had dominated the decreased bacterial biomass with higher $\mathrm{pH}$ in liming soils in the present study. In addition, our results showed that lime application reduced the soil water content, which might in turn suppress the $\mathrm{NO}_{3}{ }^{-}-\mathrm{N}$ leaching from soil. The increased inorganic $\mathrm{N}$ might have "toxicity effects or salt effects" on soil microbes and consequently suppress the microbial biomass [32]. In line with our results, studies from Wu et al. (2011) and Cox et al. (2010) also demonstrated that the microbial diversity and biomass were reduced by the increased $\mathrm{N}$ availability [19,33].

\subsection{The Impacts of Understory Removal on Soil Microbial Community}

Soil microorganisms are greatly affected by both the quantity and quality of resources, as well as the soil habitat. Soil sampling time had significant effects on soil microbial biomass and composition in this study (Figure 2, Table 3), probably due to the seasonal variations in soil temperature and/or moisture. The present study region is within a typical subtropical monsoon climate, with distinct wet-hot and dry-cold seasons. Over $83 \%$ and $66 \%$ of annual precipitation and radiation inputs to this region occur during the wet-hot season (from April to September). The temporal changes in soil microbial biomass and composition could be ascribed to the changes in moisture, soil temperature, and the substrate availability, as indicated by other studies [24].

In addition, soil sampling time had a significant interactive effect with UR on soil total PLFAs, which should be considered when conducting "before-after-control-impact" (BACI) experiments in the monsoon climate regime region. Our findings showed that understory removal significantly reduced total PLFAs, fungal PLFA, and the F: B ratio. The effects of understory plant removal on soil microbial communities have also been observed in other forest ecosystems. For instance, Winsome et al. (2017) reported that understory removal significantly reduced soil microbial biomass in a ponderosa pine plantation [34]. Tong et al. (2015) found that understory removal apparently decreased soil fungal PLFAs and the F:B ratio in a Chinese fir plantation [35]. Yin et al. (2016) found that the biomass of all microbial community groups (i.e., fungi, bacteria, arbuscular mycorrhizal fungi, and actinomycetes) decreased with decreasing understory herbs biomass in subtropical plantations, which suggested that understory vegetation would exert strong controls on soil microbial communities [36]. Zhao et al. (2012) and Giuggiola et al. (2018) also suggested that the indirect effects of understory removal on soil microclimate wound be the most likely factor affecting soil microbial community composition [20,37]. 
Furthermore, RDA showed that the increased soil temperature and decreased soil moisture derived from the understory removal treatment resulted in changes in soil microbial composition. This may be attributed to the fact that the soil microbial community was significantly correlated with soil temperature and moisture, and all of the environmental variables explained up to $92.4 \%$ of the total variance in soil microbial communities in this study (Figure 3).

It is generally accepted that soil microbial community is controlled by the bottom-up force [38,39]. Normally, understory vegetation is considered as a minor portion of biomass in a forest ecosystem and contributes less to the bottom-up force on soil decomposers than overstory plants. Wu et al. (2011) reported that the DOC remained unaffected by understory removal in both two-year and 24-year Eucalyptus plantations [19], which indicated that the bottom-up control induced by understory vegetation was minor. However, there was an apparent trend that understory removal decreased DOC $(P=0.06)$ (Table 2), and thus resulted in the decrease in fungal PLFAs in the six-year Eucalyptus plantation in this study, which was proven by the positive correlation between the fungal PLFA biomarker (i.e., 18:2w6,9) and the DOC (Figure 3). Additionally, understory removal decreased soil moisture $(P<0.01)$, and subsequently increased the fungal PLFAs, as indicated by the negative relationship between the fungal PLFA biomarker 18:2w6,9 and soil moisture (Figure 3). Consequently, the suppressing effect of understory removal on soil fungal PLFAs could be ascribed to the decrease in DOC. Furthermore, our previous study in the same experiment site found that understory removal significantly reduced the soil $\mathrm{CO}_{2}$ flux, and the biomass of understory fern occupied up to $20 \%$ of the Eucalyptus plantation [17], which indicated that the understory dominated by D. dichotoma might have a bottom-up control on soil microbial communities. Since the ecological functions of understory vegetation in a forest ecosystem largely depend on their species [21] and biomass [6,40], the differentiated results from different ecosystems indicate that the effects of understory vegetation on soil microbial communities are context dependent and require further studies.

\section{Conclusions}

In conclusion, soil microbial communities in this study were affected by both lime application and understory removal, but without any interaction. Lime application increased soil $\mathrm{pH}$ and soil $\mathrm{NO}_{3}{ }^{-}-\mathrm{N}^{-}$ content, which decreased the soil fungal and bacterial PLFAs. Understory presence is favorable for sustaining soil microclimates and providing resources for soil microorganisms. Understory removal inhibited soil total PLFAs and fungal PLFAs, and hence altered the soil microbial communities. In addition, both lime application and understory removal significantly reduced the litter decomposition rates (Figure 4), which indicates the lime application and understory removal may impact the microbe-mediated soil ecological process (i.e., soil nutrient cycling). We propose that lime application may not be suitable for the management of subtropical Eucalyptus plantations, while the understory fern D. dichotoma functions as a facilitator in Eucalyptus plantations and should not be removed. In general, our findings in this study would be helpful for the development of management practices that optimize the yield and sustainability of subtropical plantations.

Author Contributions: S.W. and Z.L. designed the experiment. S.W., Y.C., and J.Z. performed the study data collection. J.L., S.W, and Q.Y. analyzed the results. J.L. and Z.L. reviewed the article. S.W. wrote the final article. All authors approved the final version of the manuscript.

Funding: This study was funded by the National Science Foundation of China (41867007 and 31500341), Guangdong Provincial Key Laboratory of Applied Botany, South China Botanical Garden, Chinese Academy of Science (AB2016003), the Open Foundation of the State Key Laboratory of Urban and Regional Ecology of China (SKLURE2016-2-5), and the Youth Innovation Promotion Association CAS.

Acknowledgments: We thank Shenglei Fu and Weixing Zhang from Henan University for their comments and discussions on the early version of the manuscript. We also thank Xiaoli Wang and Xiaolin Zhu for their assistance in samples analysis and data collection.

Conflicts of Interest: The authors declare no conflict of interest. 


\section{References}

1. Wan, S.; Zhang, C.; Chen, Y.; Zhao, J.; Wang, X.; Wu, J.; Zhou, L.; Lin, Y.; Liu, Z.; Fu, S. The understory fern Dicranopteris dichotoma facilitates the overstory Eucalyptus trees in subtropical plantations. Ecosphere 2014, 5, 1-12. [CrossRef]

2. Leff, J.W.; Jones, S.E.; Prober, S.M.; Barberán, A.; Borer, E.T.; Firn, J.L.; Harpole, W.S.; Hobbie, S.E.; Hofmockel, K.S.; Knops, J.M.H.; et al. Consistent responses of soil microbial communities to elevated nutrient inputs in grasslands across the globe. Proc. Natl. Acad. Sci. USA 2015, 112, 10967-10972. [CrossRef]

3. Delgado-Baquerizo, M.; Maestre, F.T.; Reich, P.B.; Jeffries, T.C.; Gaitan, J.J.; Encinar, D.; Berdugo, M.; Campbell, C.D.; Singh, B.K. Microbial diversity drives multifunctionality in terrestrial ecosystems. Nat. Commun. 2016, 7, 10541. [CrossRef]

4. Narendrula-Kotha, R.; Nkongolo, K.K. Microbial response to soil liming of damaged ecosystems revealed by pyrosequencing and phospholipid fatty acid analyses. PLOS ONE 2017, 12, e0168497. [CrossRef]

5. Li, J.; Li, Z.; Wang, F.; Zou, B.; Chen, Y.; Zhao, J.; Mo, Q.; Li, Y.; Li, X.; Xia, H. Effects of nitrogen and phosphorus addition on soil microbial community in a secondary tropical forest of China. Biol. Fertil. Soils 2015, 51, 207-215. [CrossRef]

6. Zhao, J.; Wan, S.; Fu, S.; Wang, X.; Wang, M.; Liang, C.; Chen, Y.; Zhu, X. Effects of understory removal and nitrogen fertilization on soil microbial communities in Eucalyptus plantations. For. Ecol. Manag. 2013, 310, 80-86. [CrossRef]

7. Zhao, J.; Zhao, C.; Wan, S.; Wang, X.; Zhou, L.; Fu, S. Soil nematode assemblages in an acid soil as affected by lime application. Nematology 2015, 17, 179. [CrossRef]

8. Bramble, D.S.E.; Gouveia, G.A.; Ramnarine, R. Organic residues and ammonium effects on $\mathrm{CO}_{2}$ emissions and soil quality indicators in limed acid tropical soils. Soil Syst. 2019, 3, 16. [CrossRef]

9. Bakina, L.G.; Chugunova, M.V.; Zaitseva, T.B.; Nebol'sina, Z.P. The effect of liming on the complex of soil microorganisms and the humus status of a soddy-podzolic soil in a long-term experiment. Eurasian Soil Sci. 2014, 47, 110-118. [CrossRef]

10. Pennanen, T.H.; Vanhala, P.; Kiikkila, O.; Neuvonen, S.; Baath, E. Structure of a microbial community in soil after prolonged addition of low levels of simulated acid rain. Appl. Environ. Microb. 1998, 64, 2173-2180.

11. Pawlett, M.; Hopkins, D.W.; Moffett, B.F.; Harris, J.A. The effect of earthworms and liming on soil microbial communities. Biol. Fertil. Soils 2009, 45, 361-369. [CrossRef]

12. Bruneau, P.M.C.; Davidson, D.A.; Grieve, I.C.; Young, I.M.; Naoise, N. The effects of soil horizons and faunal excrement on bacterial distribution in an upland grassland soil. Fems Microb. Ecol. 2010, 52, 139-144. [CrossRef]

13. Kamal, S.; Prasad, R.; Varma, A. Soil microbial diversity in relation to heavy metals. In Soil Heavy Metals; Springer: Berlin, Heidelberg, 2010; volume 19, pp. 31-63.

14. Wang, Y.; Shi, J.; Wang, H.; Lin, Q.; Chen, X.; Chen, Y. The influence of soil heavy metals pollution on soil microbial biomass, enzyme activity, and community composition near a copper smelter. Ecotoxicol. Environ. Saf. 2007, 67, 75-81. [CrossRef]

15. Haynes, R.J.; Naidu, R. Influence of lime, fertilizer and manure applications on soil organic matter content and soil physical conditions: A review. Nutr. Cycl. Agroecosyst. 1998, 51, 123-137. [CrossRef]

16. Shi, L.; Guo, Z.; Liang, F.; Xiao, X.; Peng, C.; Zeng, P.; Feng, W.; Ran, H. Effect of liming with various water regimes on both immobilization of Cadmium and improvement of bacterial communities in Contaminated Paddy: A field experiment. Int. J. Environ. Res. Public Health 2019, 16, 498. [CrossRef]

17. Wan, S.; Zhang, C.; Chen, Y.; Zhao, J.; Zhu, X.; Wu, J.; Zhou, L.; Lin, Y.; Liu, Z.; Fu, S. Interactive effects of understory removal and fertilization on soil respiration in subtropical Eucalyptus plantations. J. Plant Ecol. 2015, 3, 284-290. [CrossRef]

18. Wang, F.; Chen, F.; Wang, G.G.; Mao, R.; Fang, X.; Wang, H.; Bu, W. Effects of experimental nitrogen addition on nutrients and nonstructural carbohydrates of dominant understory plants in a Chinese fir plantation. Forests 2019, 10, 155. [CrossRef] 
19. Wu, J.; Liu, Z.; Chen, D.; Huang, G.; Zhou, L.; Fu, S. Understory plants can make substantial contributions to soil respiration: Evidence from two subtropical plantations. Soil Biol. Biochem. 2011, 43, 2355-2357. [CrossRef]

20. Giuggiola, A.; Zweifel, R.; Feichtinger, L.M.; Vollenweider, P.; Bugmann, H.; Haeni, M.; Rigling, A. Competition for water in a xeric forest ecosystem-Effects of understory removal on soil micro-climate, growth and physiology of dominant Scots pine trees. For. Ecol. Manag. 2018, 409, 241-249. [CrossRef]

21. Nilsson, M.-C.; Wardle, D.A. Understory vegetation as a forest ecosystem driver: Evidence from the northern Swedish boreal forest. Front. Ecol. Environ. 2005, 3, 421-428. [CrossRef]

22. Wang, J.; Hai, R.; Long, Y.; Duan, W. Establishment and early growth of introduced indigenous tree species in typical plantations and shrubland in South China. For. Ecol. Manag. 2009, 7, 1293-1300. [CrossRef]

23. Li, Y.L.; Wang, S.L.; Yan, S.K. Short-term effects of understory vegetation removal on nutrient cycling in litter layer of Chinese fir plantation. Chin. J. Appl. Ecol. 2011, 22, 2560.

24. Wu, J.; Liu, Z.; Wang, X.; Sun, Y.; Zhou, L.; Lin, Y.; Fu, S. Effects of understory removal and tree girdling on soil microbial community composition and litter decomposition in two Eucalyptus plantations in South China. Funct. Ecol. 2011, 25, 921-931. [CrossRef]

25. Urcelay, C.; Díaz, S.; Gurvich, D.E.; Chapin, F.S., III; Cuevas, E.; Domínguez, L.S. Mycorrhizal community resilience in response to experimental plant functional type removals in a woody ecosystem. J. Ecol. 2010, 97, 1291-1301. [CrossRef]

26. FAO. World Referernce Base for Soil Resources 2006; World Soil Resources Report 103; FAO: Rome, Italy, 2006.

27. Bossio, D.; Scow, K. Impacts of carbon and flooding on soil microbial communities: Phospholipid fatty acid profiles and substrate utilization patterns. Microb. Ecol. 1998, 35, 265-278. [CrossRef]

28. Frostegård, Å.; Tunlid, A.; Bååth, E. Use and misuse of PLFA measurements in soils. Soil Biol. Biochem. 2011, 43, 1621-1625. [CrossRef]

29. Frostegård, Å.; Bååth, E.; Tunlio, A. Shifts in the structure of soil microbial communities in limed forests as revealed by phospholipid fatty acid analysis. Soil Biol. Biochem. 1993, 25, 723-730. [CrossRef]

30. Lin, Y.; Ye, G.; Liu, D.; Ledgard, S.; Luo, J.; Fan, J.; Yuan, J.; Chen, Z.; Ding, W. Long-term application of lime or pig manure rather than plant residues suppressed diazotroph abundance and diversity and altered community structure in an acidic Ultisol. Soil Biol. Biochem. 2018, 123, 218-228. [CrossRef]

31. Xue, D.; Huang, X.; Yao, H.; Huang, C. Effect of lime application on microbial community in acidic tea orchard soils in comparison with those in wasteland and forest soils. J. Environ. Sci. 2010, 22, 1253-1260. [CrossRef]

32. Thirukkumaran, C.M.; Parkinson, D. Microbial respiration, biomass, metabolic quotient and litter decomposition in a lodgepole pine forest floor amended with nitrogen and phosphorous fertilizers. Soil Biol. Biochem. 2000, 32, 59-66. [CrossRef]

33. Cox, F.; Barsoum, N.; Lilleskov, E.A.; Bidartondo, M.I. Nitrogen availability is a primary determinant of conifer mycorrhizas across complex environmental gradients. Ecol. Lett. 2010, 13, 1103-1113. [CrossRef]

34. Winsome, T.; Silva, L.C.R.; Scow, K.M.; Doane, T.A.; Powers, R.F.; Horwath, W.R. Plant-microbe interactions regulate carbon and nitrogen accumulation in forest soils. For. Ecol. Manag. 2017, 384, 415-423. [CrossRef]

35. He, T.X.; Li, Y.P.; Zhang, F.Y.; Wang, Q.K. Effects of understory removal on soil respiration and microbial community composition structure in a Chinese fir plantation. Chin. J. Plant Ecol. 2015, 39, 797-806.

36. Yin, K.; Zhang, L.; Chen, D.; Tian, Y.; Zhang, F.; Wen, M.; Yuan, C. Understory herb layer exerts strong controls on soil microbial communities in subtropical plantations. Sci. Rep. 2016, 6, 27066. [CrossRef]

37. Zhao, J.; Wan, S.; Li, Z.A.; Shao, Y.; Xu, G.; Liu, Z.; Zhou, L.; Fu, S. Dicranopteris-dominated understory as major driver of intensive forest ecosystem in humid subtropical and tropical region. Soil Biol. Biochem. 2012, 49, 78-87. [CrossRef]

38. Schuldt, A.; Bruelheide, H.; Buscot, F.; Assmann, T.; Erfmeier, A.; Klein, A.-M.; Ma, K.; Scholten, T.; Staab, M.; Wirth, C.; et al. Belowground top-down and aboveground bottom-up effects structure multitrophic community relationships in a biodiverse forest. Sci. Rep. 2017, 7, 4222. [CrossRef] 
39. Benítez, E.; Paredes, D.; Rodríguez, E.; Aldana, D.; González, M.; Nogales, R.; Campos, M.; Moreno, B. Bottom-up effects on herbivore-induced plant defences: A case study based on compositional patterns of rhizosphere microbial communities. Sci. Rep. 2017, 7, 6251. [CrossRef]

40. Brown, S.; Lenart, M.; Mo, J.; Kong, G. Structure and Organic Matter Dynamics of a Human-Impacted Pine Forest in a MAB Reserve of Subtropical China. Biotropica 1995, 27, 276-289. [CrossRef]

(C) 2019 by the authors. Licensee MDPI, Basel, Switzerland. This article is an open access article distributed under the terms and conditions of the Creative Commons Attribution (CC BY) license (http://creativecommons.org/licenses/by/4.0/). 